calculations on the individual performers, their previous experience of food consumed in events lasting 24 hours and the value $-700 \mathrm{k} \cdot \mathrm{cal} / \mathrm{h}$ obtained from published estimates of highest work activity, seemed to indicate that a dietary allowance of $1000 \mathrm{k}$.cal $/ \mathrm{hr}$. of cycling time might be reasonable. This figure, which obviously allowed an excess, was found useful in preparing the diets for several events when new records were established for cycling 1000 miles and for the journey between John o'Groats and Land's End. Similar events cycled in France have confirmed the use of this figure.

\title{
THE ANNUAL GENERAL MEETING
}

Report on the Eleventh Annual General Meeting of the British Association of Sport and Medicine, held at the London School of Hygiene and Tropicall Medicine at $5.30 \mathrm{p.m}$. on the 19th October, 1963, there being present 50 Members of the Association.

In the unavoidable absence of Sir Arthur Porritt, the Chair was taken by Mr. W. E. Tucker.

1) The minutes of the last Annual General Meeting were read, approved and signed.

2) The Honorary Secretary's Report was given and approved.

3) The Honorary Treasurer's Report on the accounts was given. The balance sheet which had already been circulated by post to Members, was approved.

4) Election of Officers. The Honorary Secretary informed the meeting that the Executive Committee submitted themselves for re-election en bloc for a period of one year only. This was to facilitate the re-drafting of the Constitution and Bye-Laws of the Association at present in progress. The rapid expansion in membership and activities of the Association had rendered necessary a re-organisation of the administrative structure. This re-organisation is to be reflected in the new Bye-Laws and Constitution. The Executive Committee wished to continue in 
office for a further year to complete this work of revision and to submit the new Constitution and Bye-Laws for ratification at the next Annual General Meeting or at an earlier Special General Meeting if appropriate. After some debate the proposal to re-elect the Executive Committee en bloc for a period of che year only was carried by a substantial majority. The following officers were elected:-

$\begin{array}{lll}\text { President } & - & \text { Sir Adclphe Abrahams } \\ \text { Chairman } & \text { Sir Arthur Porritt } \\ \text { Honorary Sec. } & \text { Dr. D. J. Cusson } \\ \text { Asst. Hon. Sec. } & \text { Mr. J.G.P. Williams } \\ \text { Hon. Treasurer } & - & \text { Dr. H. Evans Robson } \\ \text { Members } & - & \text { Dr. Alan Bass } \\ & \text { Dr. J. L. Blonstein } \\ & \text { Dr. Raymond Owen } \\ & \text { Brig. Glyn Hughes } \\ & \text { Mr. W. E. Tucker } \\ & \text { Mr. Peter Sebastian } \\ & \text { Mr. K. S. Duncan } \\ & \text { Mr. H. L. Davies }\end{array}$

5) Mr. McQueen proposed that a special Sub-Committee be set up to supervise programmes and selection of papers for meetings. It was pointed out that in fact such sub-committees were set up for each meeting on an ad hoc basis and that a rationalisation of this system would be included in the new Constitution and Bye-Laws. It was agreed therefore not to make any alteration in the present system for the time being.

Mr. McQueen also proposed, and this was seconded by Mr. J.G.P. Williams, and carried unanimously, that no papers should be considered for inclusion in a meeting or symposium unless received at least a month in advance of the date of that meeting or symposium.

The question of selection of papers for publication was also raised. The Honorary Secretary pointed out that there was in fact an editorial sub-committee but that its activities had been limited recently since the lamenteci death of Mr. W. D. Coltart.

There being no further business the meeting closed with a vote of thanks to $\mathrm{Mr}$. W. E. Tucker for taking the Chair. 